Acta vet. scand. $1974,15,80-89$.

From the State Veterinary Serum Laboratory, Copenhagen, Denmark.

\title{
SEROLOGICAL AND IMMUNOLOGICAL STUDIES OF PLEUROPNEUMONIA OF SWINE CAUSED BY HAEMOPHILUS PARAHAEMOLYTICUS
}

\author{
By \\ Ragnhild Nielsen
}

\begin{abstract}
NIELSEN, RAGNHILD: Serological and immunological studies of pleuropneumonia of swine caused by Haemophilus parahaemolyticus. Acta vet. scand. $1974,15,80 \longrightarrow 89$. - The development of circulating antibodies for $\mathrm{H}$. parahaemolyticus was studied in experimentally infected SPF pigs and in-contact SPF pigs. Blood serum titers were determined by a modified complement fixation test with normal SPF swine serum as a source of supplementary complement factor, and by an indirect haemagglutination test.

CF and IHA titers became positive within the first 2 weeks following exposure to $H$. parahaemolyticus, and reached peak values after 2 to 7 weeks (Figs. 1 to 3 ). The exposed pigs proved immune, in that they showed no clinical symptoms on challenge after resp. 6, 9 and 11 weeks.

While distinct titers were thus obtained with both tests in SPF swine experimentally exposed to $\mathrm{H}$. parahaemolyticus, the $\mathrm{CF}$ test proved more specific than the IHA test when the 2 tests were compared in a field outbreak of polyserositis (Glässers disease) caused by $H$. parasuis. The CF test would therefore seem to be preferable to the IHA test in field diagnostic work (Table 1).

A noticeable finding was that challenge did not elicit an anamnestic antibody response in any of the immune pigs (Figs. 1 to 3 ). This fact together with negative bacteriological findings in the animals in question would seem to suggest that the challenge dose was unable to establish a permanent infection in the respiratory tract of the immune pigs.
\end{abstract}

pleuropneumonia; complement-fixation test; Haemophilus parahaemolyticus; indirect haemagglutination test.

Nicolet et al. (1971) has described a modified complement fixation test and shown it to be of value in the diagnosis of pleuropneumonia of swine. In this test, the procomplementary property of swine serum was eliminated by heat inactivation at $60^{\circ} \mathrm{C}$. Fresh bovine serum was added as supplementary factor to 
the complement. In epidemiological studies, Bachmann (1972) found this complement fixation test superior to other serological methods in sensitivity and specificity. The present paper describes serological reactions in swine infected experimentally with Haemophilus parahaemolyticus. A modified complement fixation test was employed in which the addition of bovine serum to the solution of complement was replaced by serum from SPF swine. The sensitivity of the complement fixation test was compared with that of the indirect haemagglutination test.

\section{MATERIAL AND METHODS}

Nine 10-week-old pigs were derived from the laboratory herd, which is being maintained as an SPF unit. H. parahaemolyticus has not been isolated from pigs in this herd. The pigs were divided into three groups. Group 1 consisted of Pig No. 1 inoculated intranasally with $\mathrm{H}$. parahaemolyticus $\left(10^{6}\right.$ organisms) on the day of arrival, and Pig No. 2 in contact. Three weeks later Pig No. 5 was brought in contact. Group 2 consisted of Pigs Nos. 3 and 4 inoculated intranasally on the day of arrival with $10^{10}$ organisms. Four weeks later Pig No. 6 was brought in contact. In Group 3 (Pigs Nos. 19, 20 and 21) all 3 pigs were inoculated intranasally on the day of arrival with $10^{10}$ organisms.

All pigs were given a challenge dose of $10^{10}$ organisms at 9 weeks (Group 1), 11 weeks (Group 2) and 6 weeks (Group 3) after inoculation (p.i.).

The strain used for inoculation was a capsulated $\mathrm{H}$. parahaemolyticus (G 4226) belonging to Serotype 2 (Nicolet 1971).

The organisms were grown overnight on PPLO agar and washed off with normal saline. The bacterial suspension was diluted with saline to concentrations of $10^{6}$ and $10^{10}$ respectively. The concentration was estimated nephelometrically.

Blood samples were taken from the anterior vena cava before the animals were inoculated or brought in contact, and afterwards at weekly intervals.

After the experiment the pigs were sacrificed and a full postmortem examination carried out. Cultures were made from lungs, pleura, nasal cavity and tonsils on $5 \%$ calf-blood agar with a non-haemolytic E. coli strain streaked diametrically across the plate.

From a severe field outbreak of polyserositis (Glässers disease) in a large SPF herd a Haemophilus parasuis strain was 
isolated ( $G$ 4800). During the outbreak serum samples were obtained, and 200 of these sera were submitted to cross serological studies. The cross serological examinations were made by comparing the complement fixation reactions in the homologous systems (i. e., sera from Groups 1 to 3 against H.parahaemolyticus antigen and sera from the field outbreak against $H$. parasuis antigen) with the results obtained in the heterologous systems (i. e., sera from Groups 1 to 3 against $H$.parasuis antigen and field sera against $H$. parahaemolyticus antigen). The field sera were examined also by the indirect haemagglutination test, but only with $H$. parahaemolyticus as antigen, since it proved impracticable to coat erythrocytes with antigen from the isolated $H$. parasuis strain.

\section{Complement fixation test (CF)}

The Laboratory Branch Complement Fixation Method, adapted to Micro Technique as described in Public Health Monograph No. 74, was followed. Sera were inactivated at $60^{\circ} \mathrm{C}$ for $30 \mathrm{~min}$. The guinea-pig complement was titrated in veronal buffered diluent (VBD) containing a 1:150 dilution of unheated swine serum. This serum was obtained from normal 6- to 8-week-old SPF swine. The sera were pooled and stored at $-70^{\circ} \mathrm{C}$ in small portions.

Antigens were prepared as described by Nicolet et al. (1971) from strains G 4226 (H. parahaemolyticus) and G 4800 (H. parasuis ).

\section{Indirect haemagglutination test (IHA)}

Direct adsorption of antigen to goat erythrocytes was accomplished by following essentially the method described by Herbert (1967).

Goat's blood was collected in an equal volume of Alsever's solution. The erythrocyles were washed 3 times in phosphatebuffered saline.

A 6-hr. culture of $\mathrm{H}$. parahaemolyticus on PPLO agar was used as source of antigen. The culture was suspended in phosphate-buffered saline and disintegrated in a French pressure cell (Aminco). The disintegrated culture was centrifuged and the supernate kept as stock solution at $4^{\circ} \mathrm{C}$ with merthiolate added $(1: 10,000)$. The stock solution was tested in 10 -fold serial di- 
lutions against a known positive serum to determine the optimum concentration of antigen to be employed for coating.

Coating of erythrocytes was carried out at $37^{\circ} \mathrm{C}$ for $1 \mathrm{hr}$. After coating the cells were washed 3 times in phosphate-buffered saline and finally made up for use as a $1 \%$ suspension.

Sera were inactivated for $56^{\circ} \mathrm{C}$ for $30 \mathrm{~min}$. Heterophil agglutinins for erythrocytes were removed by absorption with packed erythrocytes at the rate of $0.25 \mathrm{ml}$ per $\mathrm{ml}$ serum diluted 1:10. The mixture was left at $37^{\circ} \mathrm{C}$ for $30 \mathrm{~min}$. After centrifugation serial dilutions were made from the supernatant.

The test was made in disposable microtitration plates with U-shaped wells. In each well $0.05 \mathrm{ml}$ serum dilution was mixed with $0.05 \mathrm{ml}$ cell suspension. The plate was left on the bench for 2 hrs.

The end point of the agglutination was determined as described by Herbert.

Controls included the initial serum dilutions with uncoated cells, and coated as well as uncoated cells in saline alone. Known positive and negative sera were included in each test.

\section{Group 1 (Fig. 1)}

\section{RESULTS}

One pig (No. 1) inoculated intranasally with $10^{6}$ organisms showed transient symptoms (dyspnoea, slight rise of temperature) beginning 1 day p.i. After 1 week these symptoms disappeared. Pig No. 2 was in contact with Pig No. 1 from the day of inoculation, and apart from slight inappetence for 3-4 days it showed no signs of disease. Pig No. 5 was brought in contact 3 weeks after the inoculation of Pig No. 1 and showed no symptoms. All 3 pigs were challenged 9 weeks p.i. with $10^{10}$ organisms. Pigs No. 1 and 2 showed no symptoms following challenge, whereas Pig No. 5 had severe respiratory distress, beginning on day 1 after challenge.

At post-mortem ( 4 months p.i.) Pig No. 1 had fibrous pleuritis on a $3 \times 3 \mathrm{~cm}$ large area of the right diaphragmatic lobe. In Pig No. 2 no lesions were found. Pig No. 5 had a small area of necrosis in the pulmonary tissue of the right diaphragmatic lobe with an overlying fibrous pleuritis. $H$. parahaemolyticus was isolated from the nasal cavity of Pig No. 1 and from necrotic lung tissue of Pig No. 5.

Serological findings are given in Fig. 1. 


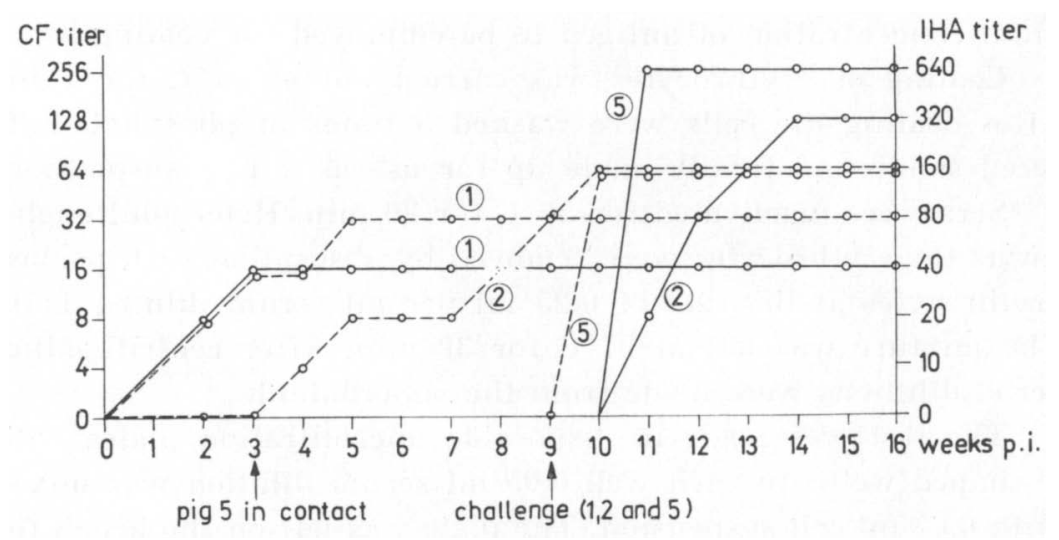

F igure 1. Serological findings in 1 pig experimentally exposed to H. parahaemolyticus (No. 1) and 2 pigs in contact (Nos. 2 and 5). CF. - ... IHA.

CF and IHA titers reached peak values in Pig No. 1 resp. 3 and 5 weeks p.i., and thereafter remained constant during the next 11 to 13 weeks. There was no increase in titers following challenge. In Pig No. 2 the IHA titer was positive after 3 to 4 weeks in contact, whereas the $\mathrm{CF}$ titer remained negative until challenge, after which it rose within 5 weeks to a peak titer of 1:128. A very abrupt rise was seen in Pig No. 5, which reached maximum IHA and CF titers resp. 1 and 2 weeks after challenge.

\section{Group 2 (Fig. 2)}

Pigs Nos. 3 and 4 were inoculated intranasally with $10^{10}$ organisms. Both pigs were acutely ill with severe respiratory distress beginning at day 1 p.i. The condition was aggravated over the following days. Therefore both pigs were treated with penicillin, after which they improved rapidly. Pig No. 6 was brought in contact 4 weeks p.i. It showed slight respiratory distress from day 1 but improved in a few days without treatment. All 3 pigs were challenged with $10^{10}$ organisms 11 weeks p.i. No signs of disease appeared following this inoculation.

At post-mortem examination ( 4 months p.i.) Pig No. 3 had a fibrous pleuritis on a $10 \times 10 \mathrm{~cm}$ large area of the left diaphragmatic lung. Pigs Nos. 4 and 6 showed no lesions of the lungs or pleura. 


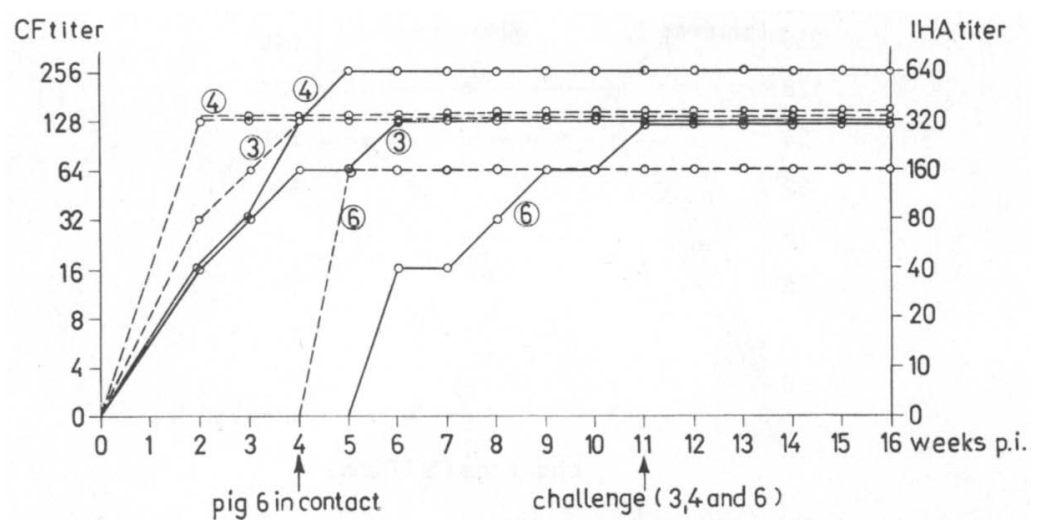

F i g u r e 2. Serological findings in 2 pigs experimentally exposed to H. parahaemolyticus (Nos. 3 and 4 ) and 1 pig in contact (No. 6). CF. -... IHA.

H. parahaemolyticus was not isolated from any of the pigs.

Serum CF and IHA titers showed the same pattern as in Group 1, but reached higher levels after primary inoculation (Pigs Nos. 3 and 4, of. Fig. 2). No anamnestic response was observed after challenge.

\section{Group 3 (Fig. 3)}

Pigs Nos. 19, 20 and 21 were inoculated with $10^{10}$ organisms intranasally. All 3 pigs showed signs of heavy respiratory distress on the following day. Pigs Nos. 19 and 20 were treated with penicillin on the first day of illness. Treatment was repeated on the following 2 days. Pig No. 21 was not treated and recovered after 2 weeks as did Pigs Nos. 19 and 20. Challenge with $10^{10}$ organisms 6 weeks p.i. was not followed by symptoms in any of the pigs.

At post-mortem (9 weeks p.i.) a bilateral fibrous pleuritis was found in Pigs Nos. 19 and 21.

H. parahaemolyticus was not isolated.

Pig No. 20 was not sacrificed.

Serological findings are given in Fig. 3. Serum CF and IHA titers reached peak values within 2 to 3 weeks after primary inoculation. No anamnestic response was observed after challenge. 


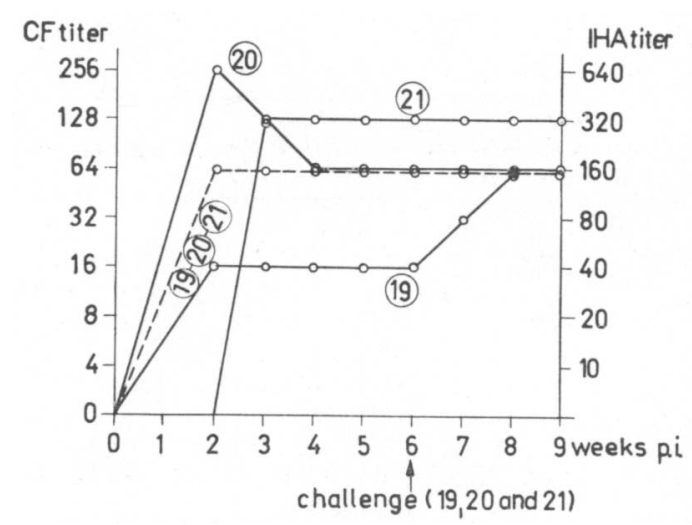

F i gure 3. Serological findings in 3 pigs experimentally exposed to $\mathrm{H}$. parahaemolyticus. - CF. .... - IHA.

\section{Cross serological examinations}

Complement fixating antibodies for $\mathbf{H}$. parasuis Strain G 4800 were not found in any of the 9 pigs experimentally infected with H. parahaemolyticus.

In Table 1 are listed the serological findings in 200 serum samples obtained during the field outbreak of polyserositis. While in the modified CF test none of the sera showed reaction with $H$. parahaemolyticus antigen, all of the 200 sera showed cross reaction with this antigen in the IHA test.

Different pools of SPF swine sera as source of supplementary factors in the CF test made no difference in the titers obtained. The known positive sera included in each set of tests remained positive with no change in titers, and the known negative sera remained negative throughout the experiment.

T a b l e 1. Serological findings in 200 serum samples obtained during a field outbreak of polyserositis.

\begin{tabular}{cccc}
\hline $\begin{array}{c}\text { Total number of } \\
\text { pigs from which } \\
\text { serum samples } \\
\text { were received }\end{array}$ & $\begin{array}{c}\text { Number of pigs } \\
\text { with CF titer for } \\
\text { H. parahaemolyticus } \\
(\text { G 4226) }\end{array}$ & $\begin{array}{c}\text { Number of pigs } \\
\text { with CF titer for } \\
\text { H. parasuis } \\
\text { (G 4800) }\end{array}$ & $\begin{array}{c}\text { Number of pigs with } \\
\text { IHA titer for } \\
\text { H. parahaemolyticus } \\
(\text { G 4226) }\end{array}$ \\
\hline 200 & 0 & $\begin{array}{c}105 \\
(\text { titers } 1 / 8\end{array}$ & $\begin{array}{c}200 \\
1 / 64)\end{array}$ \\
\hline
\end{tabular}




\section{DISCUSSION}

Pigs inoculated intranasally with Haemophilus parahaemolyticus developed circulating antibodies which could be demonstrated by IHA or by a modified CF test. Titers became positive within the first 2 weeks following inoculation, reached peak values at 2 to 7 weeks p.i., and remained high during several months thereafter. There was a tendency for IHA titers to become detectable slightly before CF titers. Challenge inoculations did not appear to stimulate an anamnestic (secondary) response (Figs. 1, 2 and 3). The experimental pigs were SPF pigs, and none of them had antibodies to $H$. parahaemolyticus before they were experimentally exposed by intranasal inoculation or had contact with inoculated pigs. After exposure all pigs showed an antibody response, most of them with high titers. High titers were also observed in pigs that underwent a subclinical infection (Nos. 2 and 6). Distinct titers were obtained with both serological tests.

When the 2 tests were compared in a field outbreak of polyserositis (Glässers disease) caused by $\mathrm{H}$. parasuis the modified CF test proved strictly specific, whereas in the IHA test all sera examined gave reaction with $H$. parahaemolyticus antigen. Accordingly, the CF test appears to be preferable to the IHA test in field diagnostic work.

The fact that the experimentally infected pigs resisted challenge after resp. 6, 9 and 11 weeks without showing clinical symptoms (Pigs Nos. 1, 3, 4, 19, 20, 21) would seem to indicate that intranasal inoculation of pigs with $\mathrm{H}$. parahaemolyticus will induce a strong immunity to that organism. Apart from 1 of the inoculated pigs (No. 1) H. parahaemolyticus could not be cultured from lungs, nasal cavity, or tonsils. A noticeable finding was that challenge did not elicit an anamnestic antibody response in any of the immune pigs. A similar phenomenon has been observed in Herpesvirus equi 1 infection (virus abortion). Immune mares with a serum antibody titer above a certain, critical level were found rapidly to reject intranasally instilled virus, not to exhibit a secondary antibody response and to be negative on blood virus culture after challenge. These findings were considered to be suggestive of a local antibody defence in the nasal cavity (Bryans 1969). The results reported in the present paper would seem to suggest that in $\mathrm{H}$. parahaemolyticus infection, too, there is a correlation between serum titer and resistance to re- 
infection, and that the defence mechanism may be exerted locally in the respiratory tract. Further studies are required to substantiate this.

\section{ACKNOWLEDGEMENTS}

The very skilful technical assistance of Miss Annie Kristoffersen is gratefully acknowledged.

\section{REFERENCES}

Bachmann, Ph.: Beitrag zur Epidemiologie der kontagiösen Pleuropneumonie beim Schwein. (Studies on the epidemiology of contagious pleuropneumonia of swine). Schweiz. Arch. Tierheilk. $1972,114,362-382$.

Herbert, W. J.: Passive haemagglutination. Handbook of Immunology. 1967, p. 720-741.

Nicolet, J.: Sur l'hémophilose du porc. III. Différenciation sérologique de Haemophilus parahaemolyticus. (Haemophilus infection in pigs. III. Serological studies on Haemophilus parahaemolyticus). Zbl. Bakt. 1971, 216, 487-495.

Nicolet, J., P. A. de Meuron \& Ph. Bachmann: Sur l'hémophilose du porc. IV. L'épreuve de déviation du complément, un test de dépistage des infections à Haemophilus parahaemolyticus. (Haemophilus infection in pigs. IV. The use of the complementfixation reaction in the diagnosis of Haemophilus parahaemolyticus infections). Schweiz. Arch. Tierheilk. 1971, 113, 191200.

Public Health Monograph No. 74: Standardized diagnostic complement fixation method and adaptation to micro test. US Dept. Health, Education and Wellfare, Public Health Service 1965.

\section{SAMMENDRAG}

Serologiske og immunologiske unders $\phi g e l s e r$ af pleuropneumoni hos svin fordrsaget af Haemophilus parahaemolyticus.

Den serologiske reaktion blev unders $\varnothing$ gt i sera af SPF grise experimentelt inficeret med Haemophilus parahaemolyticus og af grise $i$ kontakt.

Til unders $\varnothing$ gelsen blev benyttet en indirekte hæmagglutinationstest og en modificeret komplementbindingspr $\varnothing \mathrm{ve}$ med normalt SPF svineserum som supplerende faktor ved titreringen af marsvinekomplement.

Inden for de første 2 uger efter at grisene havde været udsat for smitte med Haemophilus parahaemolyticus fandtes positive CF og IHA titre. Titrene nåede maximum efter 2-7 ugers forl $\varnothing b$ (fig. $1-3$ ) . Ved re-infektion efter henholdsvis 6,9 og 11 ugers forl $\varnothing b$ viste de 
unders $\varnothing$ gte grise sig at være immune, idet kliniske symptomer ikke blev iagttaget.

I experimentelle unders $\varnothing$ gelser fandtes begge serologiske metoder anvendelige. I sammenlignende undersøgelser af sera fra et udbrud af Glässers syndrom i en SPF besætning, hvor Haemophilus parasuis blev isoleret, fandtes CF testen at være mere specifik end IHA testen (tabel 1) og den må derfor foretrækkes i besætningsdiagnostiske undersøgelser. Det må fremhæves, at challenge ikke udløste et anamnestisk respons hos de immune grise (fig. 1-3). Dette forhold sammenholdt med det negative bakteriologiske fund ved aflivning antyder, at bakterien ikke etableredes i de immune grises respirationsveje, og at resistens over for reinfektion måske findes lokalt $i$ respirationsvejene eller på næseslimhinden.

(Received September 18, 1973).

Reprints may be requested from: Ragnhild Nielsen, the State Veterinary Serum Laboratory, Bülowsvej 27, DK-1870 Copenhagen V, Denmark. 